\title{
THE EFFECT OF SERUM STORAGE FACTORS INFLUENCING THE REACTIVITY OF ANTIBODIES IN SERODIAGNOSTIC TESTS
}

\author{
Alaa El-Din Hussein, M. * and Kamel M. Ammar ${ }^{* *}$ \\ * Department of Microbiology ${ }^{* *}$ Department of Animal Medicine Faculty \\ of Veterinary Medicine, Kafr El-Sheikh Tanta University
}

\begin{abstract}
To investigate the effect of different serum storage methods on reactivity of bovine Brucella antibodies in serodiagnostic tests, sera were collected from Brucella infected cattle and stored either in a refrigerator at $4{ }^{\circ} \mathrm{C}$ or in a deep freezer at $-20{ }^{\circ} \mathrm{C}$ mean while reference serum samples were stored at $4^{\circ} \mathrm{C},-20^{\circ} \mathrm{C}$ and $-80^{\circ} \mathrm{C}$.

Monitoring of the Brucella antibody activity in stored samples, was performed by Slow Agglutination Test (SAT) on monthly basis for six months and results obtained were analyzed in three dimensions. First, between different time intervals, second, between different storage temperatures and finally between collected sera and reference sera samples.

Analysis of the results revealed a significant reduction in titer of Brucella antibodies in sera stored at- $20{ }^{\circ} \mathrm{C}$ after two months of storage,whereas no significant difference could be detected in antibodies titer for up to four months of serum storage at $4{ }^{\circ} \mathrm{C}$, meanwhile reference samples showed stability in titer of Brucella antibodies when compared with collected serum under the same storage temperatures.It was concluded that the effect of storage temperature is more or less affected by quality of serum.

Since high quality serum is the cornerstone in sero-epidemiological studies and diagnosis, we recommended the necessity of sterilization of serum by filtration. Additionally, the constancy of cooling temperature and the avoidance of refreezing and thawing during storage
\end{abstract}


should be considered in order to get accurate results from serum samples.

\section{INTRODUCTION}

Serological studies can contribute much information on the antigenic challenge in a population. A single serum sample can be tested in several ways for several purposes, as to determine disease patterns, to identify high risk groups, for establishing vaccination priorities, for evaluation vaccination protocol or for monitoring the dynamics of a disease (Moorehouse et al, 1981).

In developing countries and especially at far governorates where multiple problems do exist, such as unavailability of cold storage facilities either in the laboratories or in the field vehicles, increased distance between herds and laboratories and frequent power failures, the success of the planed epidemiological surveys and serological surveillances projects will depend upon appropriate storage of serum samples where the nature and extent of any change taking place in the serum following its preservation and storage will determine the value of the collection and hence no valid serological results could be obtained if the serum is not properly preserved. (WHO, 1959).

Storage of serum depends much on where the survey is taking place and the availability of equipments, for instance in the field without much equipment. Serum could be stored in a refrigerator at $4{ }^{\circ} \mathrm{C}$ or in a deep freezer at $-20^{\circ} \mathrm{C}$, aiming that cooling of serum to low temperatures will prevent proteolysis by preventing microbial growth and by reducing the reaction velocity (Cecchini et al, 1992).

To find out which of available storage conditions can be recommended to be used without affecting serum reactivity, the effect of the different storage temperatures on the serum was studied.

\section{MATERIAL AND METHODS}

\section{Animals:}


A total of 352 female friezian cattles, at 3-5 years of age, in a private dairy farm located at Alexandria governorate.The farm showed a problem of contagious abortion at late stage of pregnancy (7-9months of pregnancy) with retained placenta and with enlarged and oedematous aborted foeti.

\section{Serum:}

\section{A) Serum samples collected from infected animals:}

Blood samples from Brucella reactors were collected by jugular vein puncture into sterile $10 \mathrm{ml}$ tubes and allowed to clot for one hour, after the clot had formed, it was loosened from the wall of the tube to aid retraction then transferred to $4{ }^{\circ} \mathrm{C}$ for overnight. The serum was cleared by centrifugation at $1300 \mathrm{xg}$ for 15 minutes two times and collected by Pasteur pipettes into sterile tubes and stored by different storage methods according to the experimental design.

\section{B) Reference serum samples:}

Reference serum samples of Brucella infected animals were obtained kindly from Veterinary Serum and Vaccine Research Institute. Obtained serum was sterilized by filtration using $0.45 \mu \mathrm{m}$ pore size then divided in $1 \mathrm{ml}$ aliquots which were kept either at $4^{\circ} \mathrm{C}\left(\mathrm{R}_{1}\right)$ or at $-20^{\circ} \mathrm{C}\left(\mathrm{R}_{2}\right)$ or at $-80^{\circ} \mathrm{C}-\left(\mathrm{R}_{3}\right)$.

\section{Antigens:}

Brucella abortus antigens for Tube Agglutination, Rose Bengal plate and Rivanols tests were kindly obtained from Veterinary Serum and Vac-cine Research Institute, Abbassia, Cairo.

\section{Experimental Design:}

- The collected 352 sera samples were primarily tested by Rose Bengal Plate test (RBPT) and by Rivanol test and positive reactors were retested by Serum Slow Agglutination test (SAT).

- Sera samples with Brucella antibody titers 1/20 or more, as measured by SAT were divided into two portions. The first portion was kept in a 
refrigerator at $4{ }^{\circ} \mathrm{C}$ while the second portion was subdivided into two aliquots and kept in a deep freeze at $-20{ }^{\circ} \mathrm{C}$.

- SAT was first performed on stored serum as well as on reference serum samples for six months with one month interval then was performed for once, after six months of storage, for serum stored at $-20{ }^{\circ} \mathrm{C}$.

\section{Serological tests:}

A) Rose Bengal Plate test: performed according to Morgan et al. (1969).

B) Rivanol test: Performed according to Alton et al. (1975).

C) Serum slow agglutination test : performed according to Alton et al. (1988).

where briefly serial two-fold dilutions up to 1:1280 were prepared from each serum sample, whereby $0.8 \mathrm{ml}$ phenol saline was placed in the first tube, and $0.5 \mathrm{ml}$ in each of the other tubes. $0.2 \mathrm{ml}$ of the serum to be tested were added in the first tube and mixed thoroughly with the phenol saline (1:5) and then $0.5 \mathrm{ml}$ of the mixture was transferred to the second tube. After thorough mixing $0.5 \mathrm{ml}$ was transferred to the third tube, and so on, until the last tube from which after thorough mixing $0.5 \mathrm{ml}$ of the serum dilution were discarded. To each tube $0.5 \mathrm{ml}$ of antigen were added and the mixture of serum-antigen was thoroughly mixed by shaking and the tubes were then incubated at $37^{\circ} \mathrm{C}$ for 24 hours. A control tube containing $0.25 \mathrm{ml}$ antigen and $0.75 \mathrm{ml}$ phenol saline was always incubated to simulate $50 \%$ clearing whereby the highest serum dilution showing $50 \%$ or more agglutination (i.e. $50 \%$ clearing) was taken as the end titer of the serum.

In recording the results of agglutination the degree of clearing without shaking the tubes was determined as follows: 
++++ Indicated sedimentation in the form of granules and/or flakes and clear supernatant fluid.

$++\quad$ Indicated sedimentation and $75 \%$ clearing.

$+\quad$ Indicated sedimentation and $50 \%$ clearing.

$+\quad$ Indicated sedimentation and $25 \%$ clearing.

- $\quad$ No sedimentation, no clearing.

According to the standardized antigen and technique used,sera agglutinating titer were converted into international units per milliliter (IU/ml). according to $\mathbf{F A O / W H O}$ (1986) expert committee on biological standardization. (Table 1).

\section{Statistical analysis:}

Results were statistically analyzed by ANOVA (Snedecor and Cochran, 1980) using computer program according to SAS Institute (1985). Differences were considered significant when $\mathrm{P} \leq 0.05$.

\section{RESULTS AND DISCUSSION}

Serum preservation is old as immunology, its essence is based upon inhibition of microbial growth which could lead to activation of proenzymes, present in the solution by the microbial products or erythrocytic enzymes, resulting in proteolysis with a subsequent change in serum reactivity due to fragmentation of immunoglobulins (WHO,1970).

In serology, a serum preservation method is acceptable only if it does not affect the reactivity of the serum following storage by giving constant titer when tested, any reduction of titer of a serum sample when tested at a different point in time and compared to a reference can be attributed to deterioration of the sample due to the preservation method or storage temperature. 
Since proper preservation and storage of serum is an important determining factor in obtaining accurate and valid diagnostic results, and thus enabling planning of successful disease control programs, therefore the present study was planned to study the effectiveness of various storage conditions in preserving serum reactivity.

Out of 352 examined cattle, sera samples from 15 reactors to RBPT (4.26\%) having brucella antibody titers more than $1 / 20$ as confirmed by SAT (Table 2) were stored at different storages temperatures and were submitted to SAT according to the experimental design.

The obtained SAT results were compared in three dimensions; first at different time intervals, second; between different storage methods and finally between collected sera and reference sera samples, where analysis of the results revealed the following:

1- No significant difference in Brucella antibodies titer was detected for up to four months of storage in sera samples stored at $4{ }^{\circ} \mathrm{C}$ in refrigerator. (Table 3).

2- Sera samples stored in deep freeze at $-20^{\circ} \mathrm{C}$ showed significant reduction in titer of Brucella antibodies starting from the second month of preservation (Table 4).

3- In spite of that,no obvious remarkable difference in Brucella antibodies titer of most sera samples preserved at $-20^{\circ} \mathrm{C}$ when tested by SAT after six months of storage, statistical analysis revealed a slight significance reduction in antibodies titer. (Table 5).

4- Comparing sera samples stored at $4^{\circ} \mathrm{C}$ and those stored at $20^{\circ} \mathrm{C}$ revealed a significant reduction of Brucella antibodies titers in sera stored at $-20^{\circ} \mathrm{C}$ starting from the second month of storage. (Tables 3,4).

5- Meanwhile reference serum samples stored at $4{ }^{\circ} \mathrm{C}\left(\mathrm{R}_{1}\right)$ and at $-80^{\circ} \mathrm{C}$ $\left(\mathrm{R}_{3}\right)$ showed a constant titer of Brucella antibodies as tested by SAT, a slight reduction in antibodies titer was recorded in sera stored at $-20^{\circ} \mathrm{C}$ $\left(\mathrm{R}_{2}\right)$ after six months of storage (Table 3$)$.

$\overline{\bar{K} \text { Kafr El-Sheikh Vet. Med. J. Vol. } 2 \text { No. } 2 \text { (2004) }}$ 
Deep-freezing is the most recommended method for long term serum storage, however the choice of deep freezing temperature to be used is a matter of discussion. The World Health Organization Technical Report Series, $(\boldsymbol{W H O}, 1959)$ reported that depending on the facilities available the best storage temperature is $-70^{\circ} \mathrm{C}$ or lower, furthermore another important element to be considered during deep-freezing of serum is the rate of cooling, where rapid cooling to very low temperatures was proven to be the surest way of preventing changes in the protein molecule by heat denaturation proteolysis or changes in ionic strength and $\mathrm{pH}$ of the protein solution (WHO 1970). This interprets the stability of Brucella antibodies titer in reference serum samples stored at $-80^{\circ} \mathrm{C}\left(\mathrm{R}_{3}\right)$ (Table 3$)$ for up to six months of storage.

Storage at $-20^{\circ} \mathrm{C}$ may not prevent some deterioration because the serum is not completely frozen hence in a semi-solid state prone to denaturation due to stratification, dehydration and slow proteolysis. (WHO, 1959) Therefore the significant reduction in titer of Brucella antibodies in sera samples stored at $-20^{\circ} \mathrm{C}$ recorded in this study compared with those stored at $4^{\circ} \mathrm{C}$ (Table 3,4)was not surprising and have been stated by several authors. (St. George,1979; Jaccobo et al, 1991 and Adone et al, 2001).

In fact the freezing process result in denaturation of protein molecules due to dehydration which occurs as ice forms in the freezing solution leading to $25 \%$ loss of water.In addition, when a protein solution is frozen, areas of ice separated by channels of concentrated protein is formed, thus the proportion of the protein molecule which are in direct contact with ice are subjected to preferential dehydration and hence structural change.Such molecular dehydration and possibly dimerization of IgG molecules results in modification of tertiary structures and exposure of labile bonds to enzymatic activity and hence, slow proteolysis takes place in stored serum which leads initially to the production of serologically active bivalent $\mathrm{F}$ $(\mathrm{ab})_{2}$ fragments which later cleave into serologically undetectable Fab units. Meanwhile this refers to IgG cleavage a similar process occurs with IgM molecules (May and Leone. 1963). 
Storage of serum at $-20^{\circ} \mathrm{C}$ could be satisfactory as long as the temperature is kept constant and uninterrupted. (James et al. 1964 and Judd and Trentin, 1971). Hence the stability of antibodies titer in reference serum samples stored at $20^{\circ} \mathrm{C}\left(\mathrm{R}_{2}\right)$ (table 3) up to five months of storage was not surprising as they were kept in one $\mathrm{ml}$ aliquots, each of which undergo a separate test at each point in time.

Deleteriousness of thawing and refreezing was noted by Moorehouse et al. (1981) who advocate immediate testing of samples after thawing. Accordingly, we could interpret the slight reduction in antibodies titer after six months of stable storage of serum at $-20^{\circ} \mathrm{C}$ (Table 5) compared with the significant reduction starting from the second month of preservation in sera stored at the same temperature but tested monthly (Table 4). In the former the slow proteolysis is the only influencing factor, while in the latter in addition to proteolysis, the interrupted storage temperature and the freezing and thawing of serum are the determining factors. In fact the gamma-globulin fraction of serum in which most antibodies is found is the fraction which show bigger relative decrease with freezing and thawing. (Pensinger et al. 1959).

The reduction in antibodies titer detected in sera after five months of storage at $4^{\circ} \mathrm{C}$. (Table 3), was due to slow Proteolytic process occurring during storage was stated to be the cause of changes in gamma - globulin Augustin and Hayward (1960) and Skvaril (1960).

Quality of serum in terms of sterility, is an important factor to be considered in preservation of serum. Since serum deterioration is due to enzymatic degradation of serum globulins which occur by activation of pro-enzymes present in the solution, the principal enzyme is fibrinolysin which its production is striggered by metabolic products of bacterial contaminants. (Moorehouse, 1981). This explains the stability of titer of Brucella antibodies in reference sera $\left(\mathrm{R}_{1}, \mathrm{R}_{2}\right)$ if compared with sera collected and stored under the same condition (Table 3,4).

In conclusion, it is highly recommended to observe sterility during collection of blood, preparation and subsequent handling of serum and 
wherever possible serum should be sterilized by filtration in order to achieve high quality serum, as it has been shown that high quality serum can be kept at room temperature for at least eight weeks without affecting serum reactivity(Moorehouse, 1981). Second, it is very useful to subdivide serum into aliquots of about $0.5 \mathrm{ml}$ each and thus monitoring possible deterioration in serum quality by noting subsequent changes in a titer of a given antibody in a sibling aliquots tested at different times. Finally, It is recommended to ensure the constancy and uninterruption of cooling temperature during storage and to avoid refreezing and thawing of serum for prevention of fragmentation of immunoglobulin which will lead to change in serum reactivity.

Table(1):Conversion of Brucella titers to international unit(I.U/ml)according to $\boldsymbol{F A O / W H O ~ ( 1 9 8 6 )}$ expert committee on biological standardization.

\begin{tabular}{|c|c|c|}
\hline $\begin{array}{c}\text { Final dilution } \\
\text { of serum }\end{array}$ & $\begin{array}{l}\text { End point } \\
\text { reading }\end{array}$ & $\begin{array}{l}\text { International units } \\
\text { of antibody } \text { I.U./ml. }\end{array}$ \\
\hline $1 / 10$ & $\begin{array}{c}+ \\
++ \\
+++ \\
++++ \\
\end{array}$ & $\begin{array}{l}16.75 \\
20.00 \\
23.25 \\
26.50\end{array}$ \\
\hline $1 / 20$ & $\begin{array}{c}+ \\
++ \\
+++ \\
++++\end{array}$ & $\begin{array}{c}33.50 \\
40.00 \\
46.50 \\
53\end{array}$ \\
\hline $1 / 40$ & $\begin{array}{c}+ \\
++ \\
+++ \\
++++\end{array}$ & $\begin{array}{c}67 \\
80 \\
93 \\
106 \\
\end{array}$ \\
\hline $1 / 80$ & $\begin{array}{c}+ \\
++ \\
+++ \\
++++\end{array}$ & $\begin{array}{l}134 \\
160 \\
186 \\
212 \\
\end{array}$ \\
\hline $1 / 160$ & $\begin{array}{c}+ \\
++ \\
+++ \\
++++\end{array}$ & $\begin{array}{l}268 \\
320 \\
372 \\
424 \\
\end{array}$ \\
\hline $1 / 320$ & $\begin{array}{c}+ \\
++ \\
+++ \\
++++\end{array}$ & $\begin{array}{l}563 \\
640 \\
744 \\
848\end{array}$ \\
\hline
\end{tabular}

Kafr El-Sheikh Vet. Med. J. Vol. 2 No. 2 (2004) 


\begin{tabular}{|c|c|c|}
\hline \hline & + & 1072 \\
$1 / 640$ & ++ & 1280 \\
& +++ & 1488 \\
& ++++ & 1696 \\
\hline \multirow{3}{*}{$1 / 1280$} & + & 2144 \\
& ++ & 2560 \\
& +++ & 2960 \\
& ++++ & 3392 \\
\hline
\end{tabular}

Table (2): Results of serological examination of serum samples collected from cattle as tested by Slow Agglutination Test(SAT),Rose Bengal Plate Test (RBPT) and Rivanol test.

\begin{tabular}{|c||c||c|c||c|c||c|c|}
\hline \multirow{2}{*}{$\begin{array}{l}\text { Animal } \\
\text { species }\end{array}$} & \multirow{2}{*}{$\begin{array}{c}\text { Total } \\
\text { Number }\end{array}$} & \multicolumn{2}{c|}{ SAT } & \multicolumn{2}{c|}{ RBPT } & \multicolumn{2}{c|}{ Rivanol test } \\
\cline { 3 - 8 } \cline { 5 - 8 } & reactors & $\%$ & reactors & $\%$ & reactors & $\%$ \\
\hline \hline Cattle & 352 & 15 & 4.26 & 17 & 4.82 & 15 & 4.26 \\
\hline
\end{tabular}

Table (3): Brucella antibodies titre in serum samples stored in refrigerator at 4 ${ }^{\circ} \mathrm{C}$ as measured by slow agglutination test

\begin{tabular}{|c||c||c|c|c|c|c|c||}
\hline $\begin{array}{c}\text { Sample } \\
\text { Number }\end{array}$ & 0 day & 1 month & 2 month & 3 month & 4 month & 5 month & 6 month \\
\hline \hline 1 & 33.5 & 33.5 & 26.5 & 26.5 & 26.5 & 23.25 & 23.25 \\
\hline 2 & 40 & 40 & 33.5 & 33.5 & 33.5 & 26.5 & 26.5 \\
\hline 3 & 53 & 53 & 53 & 46.5 & 46.5 & 46.5 & 46.5 \\
\hline 4 & 67 & 67 & 67 & 67 & 67 & 53 & 53 \\
\hline 5 & 67 & 67 & 67 & 67 & 53 & 53 & 53 \\
\hline 6 & 80 & 80 & 80 & 80 & 80 & 80 & 67 \\
\hline 7 & 93 & 93 & 93 & 93 & 93 & 93 & 80 \\
\hline 8 & 106 & 106 & 106 & 106 & 106 & 106 & 106 \\
\hline 9 & 134 & 134 & 134 & 134 & 134 & 106 & 106 \\
\hline 10 & 134 & 134 & 134 & 134 & 134 & 134 & 106 \\
\hline 11 & 160 & 160 & 160 & 160 & 160 & 160 & 160 \\
\hline 12 & 186 & 186 & 186 & 186 & 186 & 186 & 186 \\
\hline 13 & 212 & 212 & 212 & 212 & 212 & 212 & 212 \\
\hline 14 & 320 & 320 & 320 & 320 & 320 & 320 & 320 \\
\hline 15 & 424 & 424 & 424 & 424 & 424 & 424 & 424 \\
\hline \hline
\end{tabular}

Kafr El-Sheikh Vet. Med. J. Vol. 2 No. 2 (2004) 


\begin{tabular}{|c|c|c|c|c|c|c|c|}
\hline $\begin{array}{c}\text { Means } \\
\pm \text { standard } \\
\text { deviation }\end{array}$ & $\begin{array}{c}140.63 \pm \\
105.63\end{array}$ & $\begin{array}{c}140.63 \pm \\
105.63\end{array}$ & $\begin{array}{c}139.73 \pm \\
106.53\end{array}$ & $\begin{array}{c}139.30 \pm \\
106.89\end{array}$ & $\begin{array}{c}138.36 \pm \\
107.58\end{array}$ & $\begin{array}{c}134.88 \pm * \\
109.21\end{array}$ & $\begin{array}{c}131.28 \pm * \\
110.27\end{array}$ \\
\hline$*_{1}$ & 160 & 160 & 160 & 160 & 160 & 160 & 160 \\
\hline$* * \mathrm{R}_{2}$ & 160 & 160 & 160 & 160 & 160 & 160 & 134 \\
\hline$* * * \mathrm{R}_{3}$ & 160 & 160 & 160 & 160 & 160 & 160 & 160 \\
\hline
\end{tabular}

* Significant at $\mathrm{P} \leq 0.05$.

** R1: Reference serum sample stored at $4{ }^{\circ} \mathrm{C}$.

*** R2: Reference serum sample stored at $-20^{\circ} \mathrm{C}$.

**** R3: Reference serum sample stored at $-80^{\circ} \mathrm{C}$.

Table (4): Brucella antibodies titre in serum samples stored in a deep-freezer at $-20 \circ \mathrm{C}$ as measured by slow agglutination test monthly.

\begin{tabular}{|c|c|c|c|c|c|c|c|}
\hline $\begin{array}{l}\text { Sample } \\
\text { Number }\end{array}$ & 0 day & 1 month & 2 month & 3 month & 4month & 5 month & 6 month \\
\hline 1 & 33.5 & 26.5 & 26.5 & 23.25 & 20 & 16.75 & 16.75 \\
\hline 2 & 40 & 33.5 & 33.5 & 26.5 & 26.5 & 23.25 & 20 \\
\hline 3 & 53 & 46.5 & 46.5 & 40 & 40 & 33.5 & 26.5 \\
\hline 4 & 67 & 67 & 53 & 53 & 46.5 & 46.5 & 46.5 \\
\hline 5 & 67 & 67 & 67 & 53 & 53 & 46.5 & 46.5 \\
\hline 6 & 80 & 80 & 67 & 67 & 67 & 53 & 53 \\
\hline 7 & 93 & 93 & 93 & 80 & 80 & 80 & 80 \\
\hline 8 & 106 & 106 & 106 & 106 & 93 & 93 & 93 \\
\hline 9 & 134 & 134 & 134 & 106 & 106 & 106 & 106 \\
\hline 10 & 134 & 134 & 134 & 134 & 134 & 106 & 106 \\
\hline 11 & 160 & 160 & 160 & 160 & 160 & 160 & 134 \\
\hline 12 & 186 & 186 & 186 & 186 & 186 & 186 & 160 \\
\hline 13 & 212 & 212 & 212 & 212 & 212 & 212 & 212 \\
\hline 14 & 320 & 320 & 320 & 320 & 320 & 320 & 320 \\
\hline 15 & 424 & 424 & 424 & 424 & 424 & 424 & 424 \\
\hline $\begin{array}{l}\text { Means } \\
\pm \text { standard } \\
\text { deviation }\end{array}$ & $\begin{array}{c}140.63 \pm \\
105.63\end{array}$ & $\begin{array}{l}139.3 \pm \\
106.89\end{array}$ & $\begin{array}{c}137.5 \pm^{*} \\
108.10\end{array}$ & $\begin{array}{c}132.71 \pm^{*} \\
110.42\end{array}$ & $\begin{array}{c}131.2 \pm * \\
111.21\end{array}$ & $\begin{array}{c}127.1 \pm * \\
113.02\end{array}$ & $\begin{array}{c}122.95 \pm \\
112.54\end{array}$ \\
\hline
\end{tabular}

Significant at $\mathrm{P} \leq 0.05$

Table (5): Brucella antibodies titer in serum samples after six months of storage in deep freezer at $-20{ }^{\circ} \mathrm{C}$ as measured by slow agglutination test.

\begin{tabular}{|c||c||c|}
\hline Sample number & 0 day & After 6 month \\
\hline \hline
\end{tabular}

Kafr El-Sheikh Vet. Med. J. Vol. 2 No. 2 (2004) 


\begin{tabular}{|c|c|c|}
\hline 1 & 33.5 & 26.5 \\
\hline 2 & 40 & 33.5 \\
\hline 3 & 53 & 46.5 \\
\hline 4 & 67 & 67 \\
\hline 5 & 67 & 67 \\
\hline 6 & 80 & 80 \\
\hline 7 & 93 & 93 \\
\hline 8 & 106 & 106 \\
\hline 9 & 134 & 134 \\
\hline 10 & 134 & 134 \\
\hline 11 & 160 & 160 \\
\hline 12 & 186 & 186 \\
\hline 13 & 212 & 212 \\
\hline 14 & 320 & 320 \\
\hline 15 & 24 & 424 \\
\hline $\begin{array}{c}\text { Means } \pm \text { standard } \\
\text { Deviation }\end{array}$ & $140.63 \pm 105.63$ & $138.9 \pm 106.73 *$ \\
\hline
\end{tabular}

* Significant at $\mathrm{P} \leq 0.05$.

\section{REFERENCES}

- Adone,Rosanna;Franco Ciuchini and Steven Olsen (2001): Field Validation of the use of SRB51 as antigen in an complement fixation test to identify calves vaccinated with Brucella abortus SRB51.Clinical and Diagnostical laboratory Immunology 8(2): 385-387.

- Alton, G.G; Louis M. Jones and Pietz, D. E. (1975): Laboratory tec-hniques in Brucellosis, WHO Monogr. Ser.55.

- Alton, G.G.; Jones, L.M.; Angus, R.D. and Verger, J.M. (1988): Techniques for the Brucellosis Laboratory. Institute National de la Recherche Agronomique. Paris.

- Augustin,R.and Hayward, B.J. (1960): Cleavage of Human Gamma-Globulin. Nature 185: 129-130.

- Anon, (1984): Instructions for conducting brucellosis tests. National Veterinary Service Laboratories (NVSL) Ames, Iowa, USA. 
- Cecchini G.; Bekele T. and Kasalio B. (1992): The effect of repeated freezing and thawing of serum on the activity of antibodies. Vet. Res. Commun. 16 (6) : 425-428.

- FAO/WHO(1986): Expert committee on brucellosis. $6^{\text {th }}$ Report 1986, Technical report series No. 740. World Health organization, Geneva.

- Jaccobo,R.A;Rivera,M.E; Sabarros, M. and Cabarajal, M. (1991): Blood Serum Conservation. Stability of the Immunologic properties. Vet. Arg. Vol. VIII. 72 96-101.

- James, K; Henney, C.S. and Stanworth,D.R. (1964): Structural Changes Occurring in 7s Gamma-Globulin. Nature 202: 563-566.

- Judd, K.P. and Trentin, J.J. (1971): Effect of Prolonged Storage on the Immunosuppressive Potency of Antithymocyte Globulin.Transpla-ntation 12. 83-85.

- May, D. and Leone, C. (1963): Serological Shelf Life of Serum Proteins under Various Conditions of Storage. Trans. Kans. Acad. Sci. 66 771-777.

- Moorehouse, P.D. and Hugh-Jones, M.E.(1981): Serum Banks. Vet. Bull. 51: 277 - 290.

- Morgan, W.J.B.; Mackinon, D.J. and Cullen, G.A. (1969): The Rose Bengal Plate agglutination test in the diagnosis of brucellosis. Vet. Rec., 85: 636.

- Pensinger, R.R; Reber, E.F; Ersoy, E. and Norton, H.W. (1959): A pooled Human serum as a standard and the effect of Freezing and Thawing on the Electrophoretic pattern of baby pig serum. Am. J. Vet. Res. 20: 180-183. 
- SAS Institute (1985): SAS. User's Guide Basic, Version $5^{\text {th }}$ Ed., SAS Institute Inc.; Cozy, NC.

- Skvaril, F.(1960): Changes in Outdated Human GammaGlobulin Nature 187: 129-130.

- Snedecor, G.W. and Cochran, W.G. (1980): Statistical methods. $7^{\text {th }}$ Ed., Iowa State Univ. Press, USA.

- ST. George, T.D.(1979): The Technology and Application of Sentinel Herds and Serum Banks.[Proc. Ind. Int. Symp. Vet. Epidem.[Econ. Canberra.

- WHO (1959): Immunology and Hematological Surveys Report of a Study Group. WHO Tech. Rep. Ser. 181: 30-33.

- WHO (1970): Multipurpose Serological Surveys and WHO Serum Reference Banks. WHO Tech. Rep. Ser. 454. 
تأثثر عو امل طرق حفظ الأمصال المؤثرة على فعالية الأجسام المضادة للبروسيلا

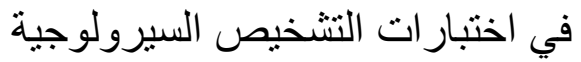

\section{علاء الدين حسين مصطقى * - كامل محمود عمار *}

\section{* قسم الميكروبيولجي ** قسم طب الحيوان - كلية الطب البيطري بكفر الثيخ - جامعة طنطا}

استهوفت هذه الدراسة معرفة تأثير طرق الحفظ المختلفة للأمصال على فعالية الأجسام المضادة

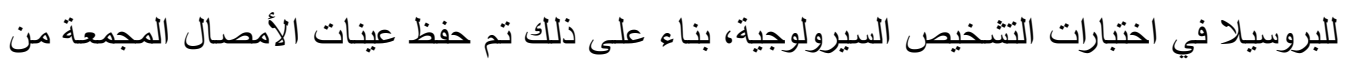
أبقار مصابة بمرض البروسيلا لمدة ستة أثشهر عند درجة حرارة 4 م أو -20ْم بينما عينات الأمصال

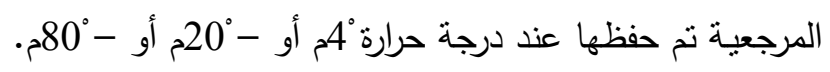

لرصد فعالية الأجسام المضـادة وتركيز الجلوبيلونـات المناعية في الأمصسال تم إجراء اختبار التلزن الأنبوبي البطئ شهرياً وعلى مدار ستة أنشر على جميع الأمصال المحفوظة ثم تم تحليل النتائج طبقاً لثلاثة محاور ـ أولاً ، طبقاً للفترات الزمنية للحفظ وثانياً بين طرق الحفظ الحفئ الحختلفة وأخيراً بين عينات الأمصال المجمعة وعينات الأمصال المرجعية.

أسفرت النتائج عن انخفاض معنوي في كمية الأجسام المضادة للبروسيلا بعد شهرين من حفظ الأمصال عند درجة حرارة - 20م، في الوقت الذي لم تظهر بـه أب فروق معنوية في كمية الأجسام

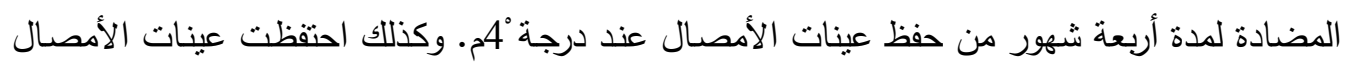
المرجعية بثبات كية الأجسام المضادة بها بالمقارنة بمثيلاتها من عينات الأمصال المجمعة والمحفوظة

$$
\text { عند نفس درجة الحرارة. }
$$

استتتج من نتائج هذه الدراسة أن تأثير درجة حرارة وسيلة حفظ الأمصال مرتبط بعامل جودة المصل، لذلك يوصي بضرورة ترشيح عينات المصل للتحري من جودته بالإضافة إلى ضرورة مراعاة ثبات درجة حرارة التبريد أثناء الحفظ مع تجنب التسييب والتجميد للعينات، هدفاً في الحصول على نتائج دقيقة من الأمصال في الاختبارات السيرولوجية. 